\title{
Research on Flipped Class Teaching Model of "Business English Translation" under the Big Data Circumstances
}

\author{
Mengqing Ye ${ }^{1, a}$ and Xiaqing $\mathrm{Liu}^{1, \mathrm{~b}}$ * \\ ${ }^{1}$ Shandong Technology and Business University, Yantai, Shandong, China 264000 \\ a985660169@qq.com, b332853225@qq.com \\ *The corresponding author
}

Keywords: Big data age; Flipped Classes; Business English Translation; Creative teaching model

\begin{abstract}
This paper has studied on the creative "Flipped Classroom" Teaching model applied to "Business English Translation" based on the big data circumstance. The paper also analyses the feasibility, and necessity of "Flipped Classes" in learning "Business English Translation" and the detailed contents of "Flipped Classes", which aims to improve the efficiency and effectiveness of business English translation class.
\end{abstract}

\section{Introduction}

The arrival of big data age was first referred by the worldwide most famous consulting company McKinsey \& Company. McKinsey \& Company said that: "Data has nowadays penetrated into every area of industry and business function, which has become a significant factor. The excavation and apply of data from people is a sign that the growth of a new wave of productivity and the arrival of the wave of consumer surplus."

According on the data from Sydney's University of Technology, in the future three days, the income of worldwide big data analysts and business analysts will increase up to $\$ 187 \mathrm{bn}$. Every day twenty-five thousand trillion bytes will be added up to the daily data pools. Under the background of Internet big data age, the Internet, electronic books, phones, IPAD are penetrating into the research of "Business English Translation" flipped classes. It is more and more possible for teachers and students to have a access of applying technology to study as well. Thus, "Business English Translation" teaching model has benefited a lot from the background of big data which benefits students and teachers a lot. The faster the big data age develops, the more supports from technology the flipped classes will get. Meanwhile, the wider flipped classes develop the wider space the big data age will have.

\section{Connotation of the Flipped Classes Teaching Model}

In 2000, Maureen Lage, Glenn Platt and Michael Treglia introduced the flipped class teaching model applied to the University of Miami on "Introduction to Economics" and achievement they achieved in the paper of "Inverting the Classroom: A Gateway to Creating an Inclusive Learning Environment". [1] Salman Khan from America delivered a speech named "Let us use videos to recreate education" in TED (Technology, Entertainment and Design Meeting). From that time, the research of flipped class has become a hot spot to extend efficient classes. More and more people will be more accustomed to it nowadays. At the same time, it is significant for teaching reform to apply "Flipped Classes" to classes nowadays.

Flipped class is a new teaching model, also named "Flipped Classroom" or "Invented Classroom". Flipped class means that readjusting the time of classroom, giving the study initiatives to students and letting students explore new knowledge by themselves. The teaching model of flipped class is inextricably linked with the theory of Knowledge internalization. In this way, students are not study passively any more, they study from their own initiatives to accomplish study tasks. [2] The teaching process is divided into 3 procedures: (1) Teachers work out study aims and study tasks giving to students and let them study the contents by themselves before the class. (2) 
Students actively have a process of knowledge internalization by watching the video from the big data platform and prepare for the coming class. (3) In the class, traditional roles between teachers and students are flipped, students have become the center of the classroom. Then they have a talk by different teams, presentations, etc. The result of the first knowledge internalized process is the concept of the second knowledge internalized. In this way, flipped class helps students accept the right concepts of knowledge. [3]

\section{Existing Problems of "Business English Translation"}

Firstly, according to the achievements and class performance of students, it is not hard to find that students are on various levels of knowledge, background and experienced. However, what an excellent translator need are versatile English talents with a solid foundation, broad cultural knowledge and proficiency in English. At the same time, it is required that a translator must have a solid mastery of Chinese language and the keen sense of his mother tongue. In this way, it is possible for students to meet the standard of "Faithfulness, Expressiveness and Elegance".

Secondly, some kinds of textbooks chosen by teachers are out of date, which cannot stimulate students' interest and enthusiasm. If students read these out-of-date books in the long run, they will not follow the space of trade and understand the new changes in "Business Translation". However, under the background of big data, texts will be selected repeatedly and elaborately to ensure to find an excellent textbook for students.

Thirdly, some teachers who teach "Business English Translation" do not have some professional and experienced knowledge, paying much attention to the translation skills and theories instead of telling the new changes of the changeable and expanded business world. In this way, students cannot form a sense of business and technology and experience the process of business translating in business advertisements, trademarks, trade names, business letters and business cards.

Last but not least, when students preparing for the "Business English Translation", they do not fully understand what they should know and how much they should know. Then when teachers are having classes, he or she will find students know little about the background knowledge of "Business English Translation", which makes teaching and study extremely inefficient.

\section{The Necessity and Feasibility of Applying "Flipped Class" Model in "Business English Translation"}

Necessity. First, "Flipped Class" is a practical way of teaching which makes use of advanced teaching ways to strengthen teaching effects. [4] Facing some clear and concise problems, teachers could directly introduce them to students because it is easy to understand. However, when they come across some abstract and obscure problems, such as changes of some economic phenomena, teachers have to use some models, software to make students aware of "Business English Translation". In this way, it is significantly necessary to use the model of "Flipped class" to make some videos and concise charts to describe some dynamic changes, making obscured statistics vivid and clear-cut.

Next, it is significantly efficient for students and teachers to save time when choosing flipped class model, keeping the space of the changing business world. Facing the competitive social environment, teachers and students had better to achieve study goals as soon as possible. At the same time, there are a lot of professional vocabularies and definitions in studying "Business English Translation". The flipped class model helps students make good preparation for the new classes. In the class, the teachers have a unified explanation to some extremely difficult contents, which also saves energy and time for students at that time.

Lastly, under the background of big data age, innovation is penetrated into every aspect of areas. Facing the changeable situation, applying "Flipped Class" to the routine classes of "Business English Translation" is totally necessary.

Feasibility. Firstly, with the development of big data age, the up-to -date internet and powerful databases exert an imperceptible influence on the flipped classes. On the one hand, it is feasible for 
teachers to make fine and vivid videos to stimulate students 'learning motivation by using many software, such as JAVA, ADVANCED STREAMING FORMAT, ACCESS, PPT. On the other hand, facing the vivid and attractive videos and power points, students are happy to have some acquaintance with some know-how about "Business English Translation". Thus, it is beneficial for students to form a global view of business English and to become rational and calm.

Besides, the feasible teaching environment and teaching ideas make a great change to the teaching models. It is possible for teachers to apply the model of "Flipped Classes" to daily teaching. At the same time, students are becoming the core of the "Business English Translation" based on the background of big data age. Studying in the model of flipped classes, students are becoming self-regulators control own pace of studying "Business English Translation". They can control the volume, timetable, place of study and become leaders of study processes. Facing the situation, students are no longer the passive receivers. [5]

Last but not least, it is also feasible for students' study features. College students have the competence of learning from videos from flipped classes and are familiar with their own levels of "Business English Translation". According to the survey on two classes with the same knowledge level of "Business English", 22\% of students think that they can perfectly accomplish the study tasks before having classes of "Business English Translation". 46\% of students think they can basically complete self-learning tasks. $30 \%$ of students have little trouble with self-learning of contents, however, they can finish them by thinking over and over. Only $2 \%$ of students said they couldn't accept this teaching model that moment and needed time to get accustomed to it. The Researches about two classes "students who are on the same knowledge level of "Business English Translation" were finished. Class one applied the traditional teaching model in learning "Business English Translation", while the Class two applied the "Flipped Class" in learning "Business English Translation". After that, two times of tests were held on and results show that "Flipped Classes "teaching model have achieved better results, as shown below:

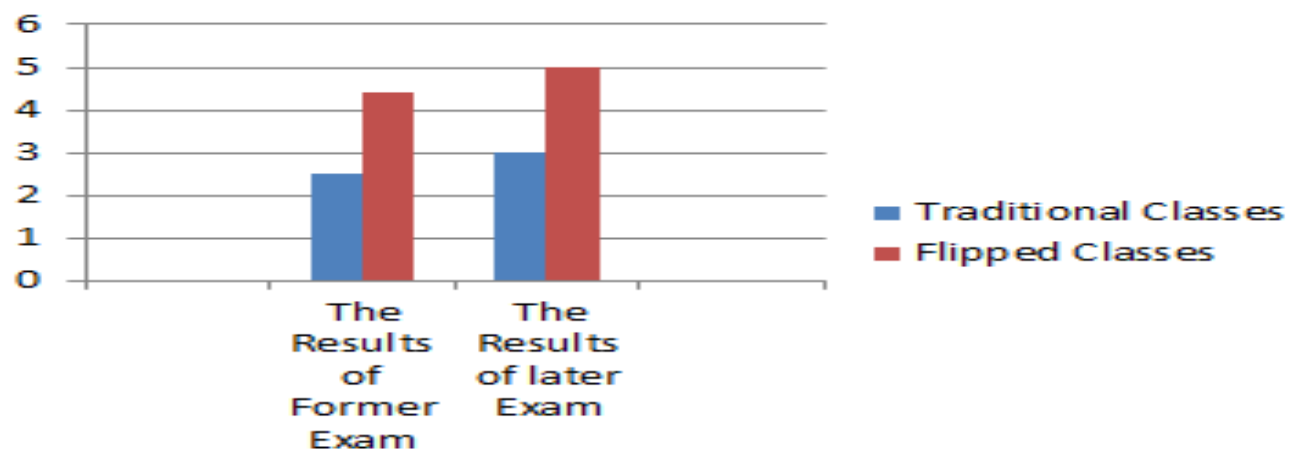

Figure 1. The comparison with Traditional Classes and Flipped Classes

In a conclusion, "Flipped Classes" teaching model is feasible in teaching "Business English Translation" under the background of big data age.

\section{The Teaching Designing of "Flipped Classes" Models}

There are two procedures of "Flipped Classes". Before the class of "Business English Translation", students have the need to watch the teaching videos and do some aimed homework. In the class, students quickly need to accomplish the tests, having a process of knowledge internalized. Last but not least, students make a conclusion based on their homework and tests. [6] The following picture shows the process of "Flipped Classes". 


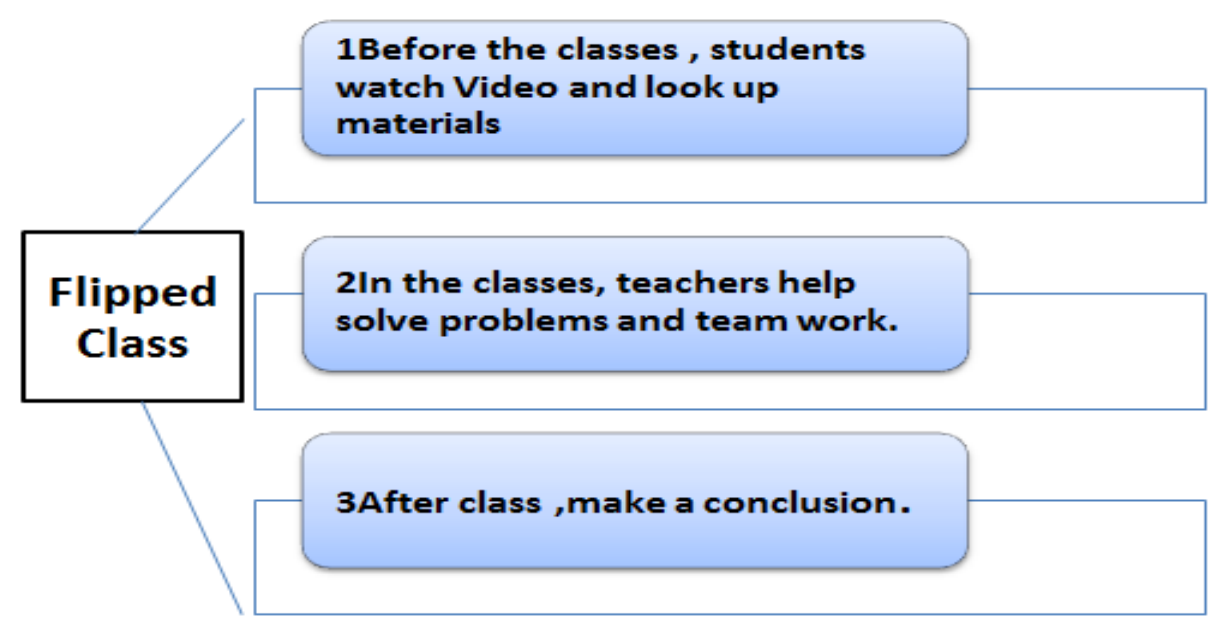

Figure 2. The comparison with Traditional Classes and Flipped Classes

(1) Teaching videos designing is a significant procedure of "Flipped Classes". The designing of teaching videos must aim at the features of the learners and impart knowledge by making the learners interested in the videos. Apart from that, the video can also be used as a media tool to provide guidance for the project or experiment to provide studying cases to the students.

For one thing, the time that students pay attention to the videos is limited, so the time of videos should be limited within 10 minutes. In the videos of "Flipped Classes", teachers had better put examples of translation in it without putting burdensome contents to annoy students. For another thing, the image of teachers had better away from videos as to forming an atmosphere of equity and harmony.

(2) Solving problems in the class is also a necessary procedure in "Flipped Classes". Students and teachers together have a deep talk and understanding of the problems that students don't understand. It is beneficial for students to have a profound and clear understanding of fragment translation in studying "Business English Translation". Facing these difficult problems, teachers and students together try their best to deal with them to achieve the excellent results. If the process of teaching and the process of studying by teachers and students is understood as "Knowledge Internalization", then the "Flipped Classes" put the "Knowledge Imparting" ahead of time and optimize the "Knowledge Internalization", which makes "Flipped Classes" meaningful.

(3)Panel discussion and self-learning together can effectively stimulate the learning interests and motivation of students. When students talk about the topic of the class in groups, they will feel a sense of freedom and self-realization, then they will put forward many new ideas and contents in further study of "Business English Classes". "Flipped Classes" apply the two ways to students. In the class, teachers should provide students with sufficient space for self-learning, which cultivates independent thinking of students. In the studying process of panel discussion, students should have a clear allocation over all the members, avoiding just top students sharing own ideas. Make sure everyone of students will join the panel discussion to express their own thoughts. It is also very crucial for teachers to guide the students pay attention their own creativity and initiatives as well.

\section{Conclusion}

With the rapid development of society, the big data age exerts an imperceptible influence on people's daily life. Facing the technological and advanced big data age, the model of "Flipped Classes" is becoming a trend nowadays. Lastly these students will have a potential to improve their inner creative qualities and creative abilities. The model of "Flipped Classes" not only brings some new ways of teaching, but also change the ideas of classes by flexible and vivid ways. Besides, it is feasible for students to apply their own subjective initiative to develop a good habit of learning 
know-how in the flipped classes. Finally, when learning "Business English Translation" under the background of "Flipped Classes", new ways and ideas enlighten many students who are so absorbed in translating business English.

Under the background of the big data age, many ways of teaching are shocked by creative ideas and thoughts. Then in the future days, "Flipped Classes" will develop faster and faster. In the long term, facing the development of "Flipped Classes", what achievements will the teachers and students carry out is not sure. In that time, will the traditional classes be replaced by "Flipped Classes"? Exploring the ways of "Flipped classes" is worthy of consideration as well.

\section{Acknowledgment}

This paper is sponsored by Shandong Social Science Planning Project (No. 14CWXJ49).

\section{References}

[1] Lage, M. J.,Platt, G. J. \& Treglia, M. (2000). Inverting the classroom: A gateway to creating an inclusive learning environment. Journal of Economic Education.

[2] Chu Lingyun. Research on the teaching mode of "business English translation" in the background of big data [J]. Heilongjiang Education (Higher Education Research \& Appraisal), 2016(4)

[3] Zhao Xinglong. Knowledge internalization and teaching models designing in flipped classroom [J]. Modern Distance Education Research, 2014(2):55-61

[4] Song Chaoxia, Yu Qiding. Research on projects of teaching models based on flipped classroom [J]. Modern Distance Education Research, 2014(1):96-104.

[5] Lu Haiyan. The feasible analysis in college English teaching based on the models of flipped classroom [J]. Computer-assisted Foreign Language Education, 2014(4):33-36.

[6] Zhong Xiaoliu, Song Shuqiang, Jiao Lizhen. Teaching models designing based on flipped classroom in information systems [J]. Open Education Research, 2013, 19(1):58-64. 